\title{
Research on the Impact of Environmental Information Disclosure Index on Enterprise Value*
}

\author{
Jianlai Gao \\ College of Economics and Management \\ Tianjin University of Science and Technology \\ Tianjin, China 300000
}

\author{
Youyuan Wang \\ College of Economics and Management \\ Tianjin University of Science and Technology \\ Tianjin, China 300000
}

\begin{abstract}
Enterprises are increasingly damaging to the environment. In order to protect the environment and implement the strategy of sustainable development, the community has paid more attention to these problems, so the disclosure of environmental information is becoming more and more important. We select 94 listed companies of heavy polluting industries in Shanghai stock exchange as research samples. The relationship between corporate environmental disclosure index and firm value is studied by multiple linear regressions. The results show that the corporate environmental disclosure index has a significant negative correlation with the firm value. That is, the higher the enterprise environmental information disclosure index is, the lower the firm value is. Meanwhile, the study also shows that the net profit margin on sales has a significant positive correlation with the firm value, and the capital density has a significant negative correlation with the firm value.
\end{abstract}

Keywords-environmental disclosure index; firm value; relation

\section{INTRODUCTION}

In recent years, with the rapid advancement of science and technology and the rapid development of the economy, the daily activities of many enterprises have increasingly damaged the natural and ecological environment, exposing specific problems such as global warming and increasing greenhouse effect. To a certain extent, this has hindered the sustainable development of the world economy and has gradually become the focus of global attention. It has aroused widespread concern among people from all walks of life and has become one of the hotspots of relevant scholars. As a result, the mechanism for companies to disclose environmental information has emerged, which is one of the most practical ways to conduct environment governance in the world. Nowadays, our country has been committed to vigorously developing and establishing a diversified environmental information disclosure mechanism for management institutions, related institutions and enterprises, and public opinion, and strongly encourages and implements environmental quality, energy conservation and environmental protection. Then, whether there is a connection between the disclosure of corporate environmental information and the corporate value that most stakeholders care about, is worthy of in-depth exploration by scholars from home and abroad. According to the results of previous research in related fields, it can be concluded that the disclosure of environmental information by enterprises affects the value of enterprises to a certain extent. In the context of China's economic transformation, the disclosure of environmental information, the corresponding government supervision and the public awareness are still in their infancy. Relevant research, and further exploration in whether there is a link between the environmental information disclosure and the corporate value of listed companies can be of great significance for optimizing corporate environmental information disclosure behavior, and improve the government's relevant management methods and promote China's all-round sustainable development and environmental protection.

In this paper the author uses 94 high-pollution enterprises in the Shanghai Stock Exchange as the data source object, and uses the corporate environmental information disclosure index as a key indicator to conduct a correlation study between the enterprise environmental information disclosure index and the enterprise value. In this way, it proposes to optimize the disclosure of corporate environmental information and to make recommendations for the positive role of disclosure of environmental information. The contributions that this paper may have are as follows: First, the basic principle analysis is proposed, which has certain reference value for the research on the impact of the enterprise environmental information disclosure index on the enterprise value. At the same time, it also provides the relevant government departments to protect the environment and achieve sustainable economic development. The development policies and measures have certain reference value. Secondly, the data in this paper comes from the latest three years of corporate environmental information disclosure index report, using the latest and more authoritative data, and contributing to our further research in related fields; Third, this paper explores the conclusion that the corporate environmental information disclosure index is significantly negatively correlated with its value, and the argumentation and narrative is a useful supplement to the related topics of exploring the impact of environmental information disclosure index on corporate value.

*CLC number: F275; F224 Document code: A 


\section{THEORETICAL ANALYSIS AND RESEARCH HYPOTHESIS}

\section{A. Theoretical Analysis of the Impact of Corporate Environmental Information Disclosure Index on Corporate Value}

One side holds the idea that there is significantly positively correlation between them. The issue of the correlation between corporate environmental information disclosure and corporate value originated from Belkaoui's market reaction research on disclosure of environmental information. In 1976, he proposed that companies which disclose information on pollution control expenditures can achieve a significant positive effect on the securities market in a short period [1]. Wu Hongjun used the chemical-type company from 2006 to 2009 in the Shanghai-Shenzhen Ashare market as a research sample, and observed that the company's environmental information disclosure quality and its environmental performance showed a significant positive correlation, and when a company disclosed a large amount of environmental information, it can promote its corporate value. He also found that enterprises can promote their own environmental information disclosure level to promote the decline of their equity capital cost. However, the environmental information required to be disclosed must be specific and verifiable. Only then can it really reduce the cost of equity capital [2]. In 2011, in the selected the relevant data of 647 listed companies from 2005 to 2009, Zhang Shuhui replaced the expected cash flow with free cash flow per share, and established the basic theoretical basis for the impact of corporate environmental information disclosure on its value. She eventually made a conclusion that enhancing the quality of the company's environmental information disclosure can increase the value of its corporate value, and creatively proposes the improvement of expected cash flow caused by corporate environmental information disclosure, which is the main reason for the positive correlation between corporate disclosure of environmental information and corporate value [3]. In 2013, foreign scholars including Clarkson conducted in-depth exploration of the listed data sources of five polluting industries, including mining, oil and gas, papermaking, chemical industry and public utilities, which were reported by the US Environmental Protection Department in 2003 and 2006. Regarding whether the company's voluntary environmental information disclosure has added value to the external investors' estimation of the company's value, reliability is used as the basis for dividing different environmental information, and the environmental information is divided into two parts: soft disclosure and hard disclosure. The disclosure of corporate environmental information is conducive to obtaining additional information related to its value, which means that the disclosure of corporate environmental information is conducive to increasing its value, but they also proposed the reasons for corporate environmental information disclosure to help improve corporate value. It is the expected cash flow effect, and there is no significant relationship with the cost of equity capital [4]. Moreover, according to the theory of social capital and the theory of key stakeholders, in 2006, Li Zheng concluded that in the long run, it is not harmful to the company's value to take the initiative to shoulder the corresponding social responsibility [5].

The other side insists that there is a significant negative correlation. In 1983, Shane \& Spicer used EAP's information on the company's pollution reduction and made a conclusion after several arguments that corporate value and environmental information disclosure were negatively correlated [6]. Hamilton used the event study method and found that after environmental incidents, bad environmental information disclosure would cause the company's stock price to fall, and he found that if the company disclosed more environmental information before the environmental incident, its stock price fell in lower degree [7]. Richardson \& Welker explained the correlation between environmental information disclosure and corporate value from the perspective of the correlation between corporate social responsibility disclosure and the cost of ownership of the owner's equity. The crosssection of listed companies in Canada from 1990 to 1992 was selected. As a data source, the study concluded that the disclosure of corporate social responsibility information can directly cause changes in the cost of equity capital, and there is a significant positive correlation between the two, that is, the disclosure of corporate environmental information is not conducive to the improvement of its own value [8]. Plumlee divided the 2000-2004 samples into five categories: medicine, food and beverage, power generation, chemicals, oil and gas to explore the correlation between corporate environmental information disclosure and its value. The results show that the quality of voluntary environmental information disclosure is explored. Among the correlations of enterprise values, the disclosure methods and industry categories play a regulatory role, while in nonenvironmentally sensitive company there is negative correlation between their active disclosure of the quality of environmental information and its expected cash flow [9].

\section{B. Proposal for Research Hypothesis}

In summary, the global scholars hold different ideas and opinions on the correlation between corporate environmental information disclosure and corporate value, each having its own merits. In this paper, the author studied the specific situation of China's corporate environmental information disclosure index by using the latest data, taking into account the period of China's economy and the basic national conditions and proposed the following assumptions:

Hypothesis 1: Corporate Environmental Disclosure Index (EDI) is significantly negatively correlated with corporate value (TobinQ).

Hypothesis 2: Capital density (CD) is significantly positively correlated with corporate value (TobinQ).

Hypothesis 3: The net profit margin (NPM) is significantly positively correlated with the corporate value (TobinQ). 


\section{RESEARCH DESIGN}

\section{A. Determination of Research Samples and Sources of the Data}

Based on the report of corporate environmental information disclosure index at the end of 2016, mid-2017 and in 2017, this paper selects 94 enterprises from the heavily polluted industries of Shanghai Stock Exchange as a research sample. The screening process from all the data in the 3 Environmental Information Disclosure Index reports is as follows: (1) Deleted the listed company that did not exist in the 3rd report; (2) Deleted the listed company with incomplete data; (3) Deleted the ST Class of companies. Finally, the data of 94 enterprises were selected and the corporate environmental information disclosure index of these 3 reports was selected as the data basis of the environmental information disclosure index of this paper. The financial raw indicators such as the remaining variable sales net interest rate, Tobin $\mathrm{Q}$ value, price-to-book ratio, firm size, asset turnover rate, capital density, asset-liability ratio, comprehensive risk level, and operating income growth rate all come from the Wind database. The analysis of the data was processed with the STATA software.

\section{B. Selection of Control Variables}

TABLE I. SPECIFIC DEFINITION OF VARIABLES

\begin{tabular}{|c|c|c|}
\hline Variable symbol & Variable name & Variable description \\
\hline TobinQ & Corporation value & (total market value + book value of all liabilities) / book value of all assets \\
\hline EDI & $\begin{array}{l}\text { Corporate Environmental Information } \\
\text { Disclosure Index }\end{array}$ & $\begin{array}{l}\text { The corporate environmental information disclosure index is based on economic, legal, } \\
\text { policy, and management perspectives (covering carbon emissions, etc.) to observe the } \\
\text { external disclosure of the company's internal environmental information. Based on } \\
\text { summarizing many relevant global research and practical applications, the above four } \\
\text { angles are classified as a first-class, and then } 21 \text { types of second-class dimensions are } \\
\text { listed, and a comprehensive interpretive structure is established to evaluate and compare } \\
\text { the level and quality of high-pollution companies and their environmental information } \\
\text { disclosure. }\end{array}$ \\
\hline SIZE & Enterprise scale & The natural log of all assets at the end of the year \\
\hline NPM & net profit margin on sales & Profit after tax/operating income \\
\hline $\mathrm{PB}$ & $\mathrm{PB}$ (price/book value ratio) & Market value per share/Net asset value per share \\
\hline AT & Asset turnover & gross operating income/total assets \\
\hline GR & revenue growth rate & $\begin{array}{l}\text { (current sales revenue - sales revenue of the previous period) / sales revenue of the } \\
\text { previous period }\end{array}$ \\
\hline $\mathrm{CD}$ & Capital density & Operating income / shareholders' equity \\
\hline LEV & Assets and liabilities & Liabilities/total assets \\
\hline BETA & Comprehensive risk level & Annual comprehensive Beta \\
\hline
\end{tabular}

\section{Construction of Empirical Model}

The specific regression model for the empirical analysis and discussion of the correlation between environmental information disclosure and corporate value is:

Tobin $Q_{i}=\alpha_{0}+\alpha_{1} E D I_{i}+\alpha_{2} S I Z E_{i}+\alpha_{3} N P M_{i}+\alpha_{4} P B_{i}+\alpha_{5} A T_{i}+\alpha_{6} G R_{i}+\alpha_{7} C D_{i}+\alpha_{8} L E V+\alpha_{9} B E T A_{i}+\varepsilon_{i}$

\section{ANALYSIS OF EMPIRICAL RESULTS}

\section{A. Descriptive Statistics}

"Table II" shows the results of descriptive statistics for each of the study variables.

TABLE II. DESCRIPTIVE STATISTICS

\begin{tabular}{llllll}
\hline Variable & Mean & \multicolumn{1}{c}{ Sd } & \multicolumn{1}{c}{ Min } & \multicolumn{1}{c}{ P50 } & \multicolumn{1}{c}{ Max } \\
\hline TobinQ & 1.773 & 1.394 & 0.715 & 1.373 & 14.447 \\
EDI & 42.646 & 16.874 & 11.320 & 41.500 & 90.570 \\
SIZE & 23.504 & 1.348 & 19.500 & 23.555 & 28.100 \\
NPM & 0.056 & 0.185 & -2.221 & 0.055 & 0.513 \\
PB & 2.724 & 11.783 & -153.002 & 2.077 & 77.409 \\
AT & 0.578 & 0.457 & 0.021 & 0.480 & 3.562 \\
GR & 0.261 & 0.551 & -0.761 & 0.165 & 4.508 \\
CD & 1.275 & 5.957 & -84.721 & 1.128 & 47.369 \\
LEV & 0.539 & 0.183 & 0.137 & 0.563 & 1.031 \\
BETA & 1.271 & 0.652 & -0.398 & 1.220 & 4.535 \\
\hline
\end{tabular}




\section{B. Correlation Analysis}

TABLE III. CORRELATION ANALYSIS

\begin{tabular}{|c|c|c|c|c|c|c|c|c|c|c|}
\hline & TobinQ & EDI & SIZE & NPM & PB & AT & GR & CD & LEV & BETA \\
\hline TobinQ & 1 & & & & & & & & & \\
\hline EDI & $\begin{array}{l}- \\
0.228 * * *\end{array}$ & 1 & & & & & & & & \\
\hline SIZE & $\begin{array}{l}- \\
0.547 * * *\end{array}$ & $0.361 * * *$ & 1 & & & & & & & \\
\hline NPM & 0.036 & 0.068 & 0.077 & 1 & & & & & & \\
\hline PB & $0.474 * * *$ & -0.032 & $\overline{0}-177 * * *$ & 0.051 & 1 & & & & & \\
\hline AT & 0.036 & 0.073 & -0.093 & 0.041 & -0.012 & 1 & & & & \\
\hline GR & 0.047 & -0.003 & $0.102 *$ & $0.210 * * *$ & 0.034 & -0.007 & 1 & & & \\
\hline $\mathrm{CD}$ & -0.028 & 0.061 & 0.049 & $0.107 *$ & $0.807 * * *$ & $0.149 * *$ & 0.019 & 1 & & \\
\hline LEV & $\overline{-}-197 * * *$ & $0.184 * * *$ & $0.364 * * *$ & $\overline{-}-322 * * *$ & -0.049 & $\begin{array}{l}- \\
0.217 * * *\end{array}$ & -0.058 & $\begin{array}{l}- \\
0.015\end{array}$ & 1 & \\
\hline BETA & $-\overline{0.215^{* * *}}$ & 0.020 & -0.071 & $\begin{array}{l}- \\
0.163^{* * * *}\end{array}$ & -0.090 & -0.014 & $0.147 * *$ & 0.014 & 0.090 & 1 \\
\hline
\end{tabular}

a. $* * *, * *, *, *$ are significant at the level of $1 \%, 5 \%$ and $10 \%$ respectively.

\section{Basic Regression Results of Enterprise Environmental} Information Disclosure Index and Enterprise Value

By using the STATA software, we substituted the dependent variable, Tobin $\mathrm{Q}$ and the independent variable, the corporate environmental information disclosure index
(EDI) and the control variables into the regression equation, in the OLS least squares method, and found there is heteroscedasticity. The data was further processed by a weighted least squares method, and the processing results are shown in "Table IV".

TABLE IV.

BASIC REGRESSION ANALYSIS RESULTS OF CORPORATE ENVIRONMENTAL INFORMATION DISCLOSURE INDEX AND ENTERPRISE VALUE

\begin{tabular}{|c|c|c|c|c|}
\hline & $\begin{array}{c}(1.1) \\
\text { TobinQ } \\
\end{array}$ & $\begin{array}{c}(1.2) \\
\text { TobinQ } \\
\end{array}$ & $\begin{array}{c}(1.3) \\
\text { TobinQ } \\
\end{array}$ & $\begin{array}{l}(1.3) \\
\text { VIF } \\
\end{array}$ \\
\hline \multirow[t]{2}{*}{ EDI } & $-0.0049^{*}$ & $-0.0051 * *$ & $-0.0033^{*} *$ & 1.19 \\
\hline & -1.84 & -2.17 & -2.15 & \\
\hline \multirow[t]{2}{*}{ SIZE } & $-0.2902 * * *$ & $-0.2826 * * *$ & $-0.1995 * * *$ & 1.64 \\
\hline & -9.22 & -9.60 & -9.34 & \\
\hline \multirow[t]{2}{*}{ NPM } & $0.3764 *$ & 0.1599 & $0.5611^{* * *}$ & 1.27 \\
\hline & 1.67 & 0.77 & 6.64 & \\
\hline \multirow[t]{2}{*}{ PB } & & $0.0098^{* * *}$ & $0.1554 * * *$ & 3.91 \\
\hline & & 2.92 & 24.07 & \\
\hline \multirow[t]{2}{*}{ AT } & & $0.1861^{* *}$ & $0.6158^{* * * *}$ & 1.19 \\
\hline & & 2.03 & 8.52 & \\
\hline \multirow[t]{2}{*}{ GR } & & 0.1716 & 0.0997* & 1.12 \\
\hline & & 1.57 & 1.74 & \\
\hline \multirow[t]{2}{*}{ CD } & & & $-0.2175 * * *$ & 3.85 \\
\hline & & & -19.81 & \\
\hline \multirow[t]{2}{*}{ LEV } & & & $0.3759 * *$ & 1.42 \\
\hline & & & 2.02 & \\
\hline \multirow[t]{2}{*}{ BETA } & & & $-0.1417 * * *$ & 1.16 \\
\hline & & & -4.00 & \\
\hline \multirow[t]{2}{*}{ Cons } & $8.6992 * * *$ & $8.3596^{* * * *}$ & $5.9785^{* * *}$ & \\
\hline & 11.84 & 12.21 & 11.75 & \\
\hline Adj.R-sq & 0.2755 & 0.3115 & 0.7754 & \\
\hline Model F statistic & 36.62 & 22.19 & 108.76 & \\
\hline Model sig. value & 0.0000 & 0.0000 & 0.0000 & \\
\hline $\mathrm{N}$ & 282 & 282 & 282 & \\
\hline
\end{tabular}




\section{Robustness Test}

A regression analysis of each model again proves that the model is indeed robust and proves that the conclusions are still true for the hypothesis.

TABLE V. ROBUSTNESS TEST

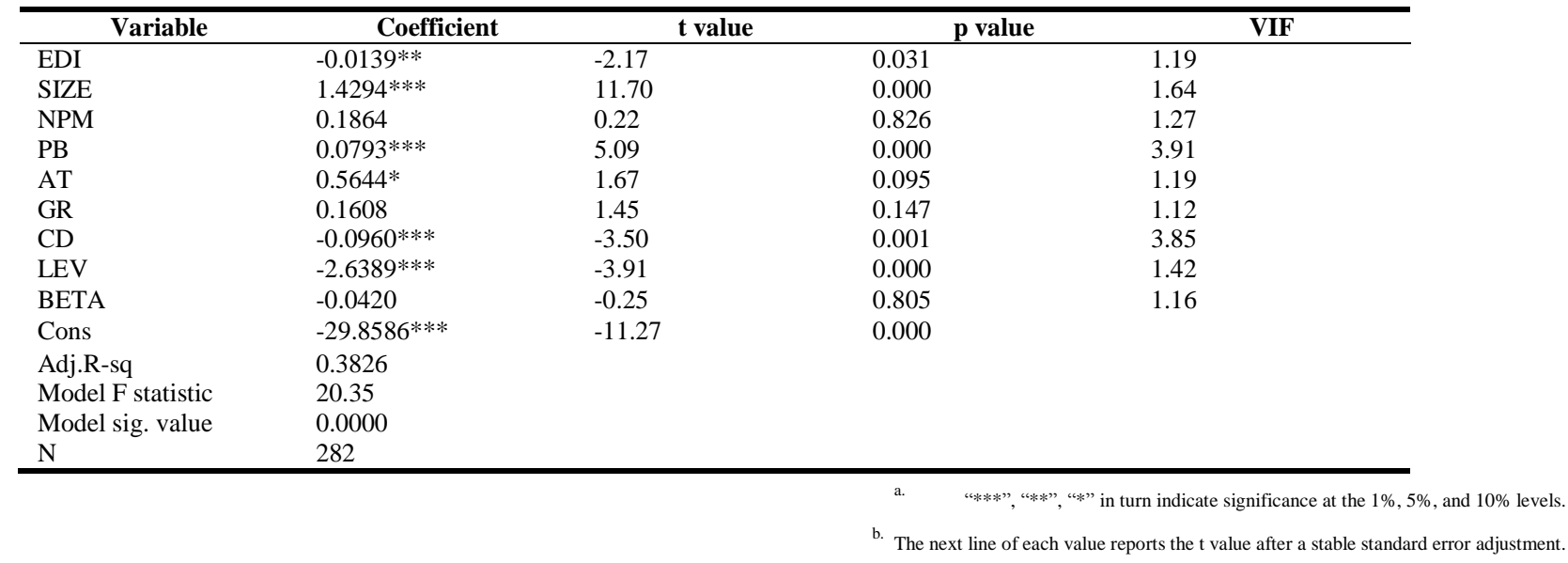

\section{CONCLUSION AND SUGGESTION}

\section{A. Research Conclusion}

The corporate environmental information disclosure index is significantly negatively correlated with corporate value. The size of the company is significantly negatively correlated with the value of the company. The company's net sales margin is significantly positively correlated with corporate value. There is a significant positive correlation between the company's P/B ratio and corporate value. The company's asset turnover rate is significantly positively correlated with the company's value. The growth rate of business revenue is positively correlated with the value of the company, but there is a significant negative correlation between the company's capital density and corporate value. The company's asset-liability ratio is significantly positively correlated with corporate value. The comprehensive risk level of a company is significantly negatively correlated with the value of the company.

\section{B. Suggestion}

The disclosure of environmental information by listed companies hinders the improvement of corporate value, which will increase the burden of disclosure costs of enterprises, and even be regarded by the public as a company that damages the environment or has high pollution, causing damage to their corporate reputation. As a result, it may cause the company to negatively disclose disclosure of environmental information, which hinders China's comprehensive sustainable development. In view of this, the following policy recommendations are proposed: First, the government needs to improve and optimize the system for disclosure of environmental information. That means we need establish a more rigorous environmental information disclosure system, which ensures that the disclosure of environmental information in the capital market is a positive pricing mechanism in which companies can receive a positive effect while they disclose higher levels of environmental information. Second, the government needs to increase the supervision of environmental information disclosure. It should vigorously support the enterprises that perform well in the disclosure of environmental information, and adopt effective and preferential incentive policies to effectively punish the companies which violate regulation or perfunctorily disclose environmental information. So that the rewards and punishments are clear, that is to say, the two major levers of economic and administrative are used to encourage enterprises to disclose higher quality environmental information. Third, the government needs to vigorously develop audits on environmental information disclosure in case the environmental information disclosed by the company is untrue and fraudulent. Fourth, the government needs to issue more specific and professional laws and regulations, and the issue of corporate environmental information disclosure is clearly regulated from the perspective of law.

\section{REFERENCES}

[1] Belkaoui A. The Impact of the Disclosure of the Environmental Effects of Organizational Behavior on the Market[J]. Financial Management, 1976, 5(4):26-31.

[2] Wu Hongjun. Environmental Information Disclosure, Environmental Performance and Equity Capital Costs[J]. Journal of Xiamen University(A Quarterly for Studies in Arts \& Social Sciences), 2014(3):129-138.

[3] Zhang Shuhui, Shi Xuanxuan, Wen Lei. Can environmental information disclosure enhance corporate value? - Evidence from Shanghai stock market[J]. Comparative Economic \& Social Systems, 2011(6):166-173. 
[4] Clarkson P M, Fang X, Li Y, et al. The Relevance of Environmental Disclosures: Are such Disclosures Incrementally Informative? [J]. Journal of Accounting \& Public Policy, 2013, 32(5):410-431.

[5] Li Zheng. Research on Correlation between Corporate Social Responsibility and Corporate Value - Evidence from Shanghai Listed Companies[J]. China's Industrial Economics, 2006(2): 77-83.

[6] Shane P B, Spicer B H. Market Response to Environmental Information Produced outside the Firm[J]. Accounting Review, 1983, 58(3):521-538.

[7] Hamilton J T. Pollution as News: Media and Stock Market Reactions to the Toxics Release Inventory Data[J]. Journal of Environmental Economics \& Management, 2004, 28(1):98-113.

[8] Richardson A J, Welker M. Social Disclosure, Financial Disclosure and the Cost of Equity Capital[J]. Accounting Organizations \& Society, 2001, 26(7):597-616.

[9] Plumlee M,Brown D, Marshall S.The Impact of Voluntary Environmental Disclosure Quality on Firm Value[J]. Social Science Electronic Publishing, 2009, 2009(1).

[10] Murray A, Sinclair D, Power D, et al. Do Financial Markets Care about Social and Environmental Disclosure?: Further Evidence and Exploration from the UK[J]. Accounting,2006, 19(2):228-255.

[11] Yuan Yang. Environmental Information Disclosure Quality and Equity Financing Cost - Evidence from Shanghai A-share Heavy Pollution Industry[J]. Journal of Zhongnan University of Economics and Law, 2014, No.202(1):126-136.

[12] Richardson A J,Welker M,Hutchinson I R.Managing Capital Market Reactions to Corporate Social Resposibility[J]. International Journal of Management Reviews, 1999, 1(1):17-43.

[13] Freedman M, Wasley C. The association between environmental performance and environmental disclosure in annual reports and 10Ks[J].Advances in Public Interest Accounting,1990, 3:183-193. 